\title{
Management guidelines of penile cancer- a contemporary review of sub-Saharan Africa
}

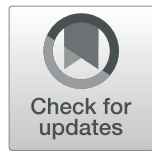

\author{
Ayun Cassell ${ }^{12^{*}}$, Bashir Yunusa ${ }^{2}$, Burgess Manobah² and Desire Wambo
}

\begin{abstract}
Background: Penile cancer is a rare malignancy with prevalence higher in areas of high Human Papilloma Virus (HPV) such as Africa, Asia and South America. In middle- and low-income countries where circumcision is not routinely practiced, the rate of penile cancer could be ten times higher.

Main body of the abstract: A literature review was conducted from 1992 to 2019 using PubMed, Google Scholar, African Journal Online and Google with inclusion of 27 publications with emphasis on the Sub-Saharan literature. Findings revealed that most men with penile cancer in Sub-Saharan Africa (SSA) present with locally advanced to advanced disease with devastating consequences. The option of penile sparing procedure is reduced with most treatment option directed to mutilating surgeries. The lack of appropriate chemotherapy and radiotherapy worsens the prognosis in the region.
\end{abstract}

Short conclusion: Human Papilloma Virus (HPV) vaccination may not be cost-effective for most regions in SSA. Therefore, early childhood circumcision might be the best advocated alternative for prevention.

Keywords: Human papilloma virus, Penectomy, Penile Cancer, Sub-Saharan Africa

\section{Introduction}

Penile cancer is a rare malignancy in Europe and America with an incidence of $<1 / 100,000$ men [1]. This frequency is much higher in Africa, Asia, South America and account for up to $10 \%$ of cancer in some region. The prevalence of penile cancer is higher in nations with Human Papilloma Virus (HPV) Infection. The age adjusted incidence in Brazil is about 8.3/100,000 [2] men and was even higher in Uganda (commonest tumor in men) in the 1960s [3]. The incidence in Uganda has declined steadily probably due to urbanization, better health system and improved hygiene to a rate of 3 to 4/100,000 men [3].

The incidence of the penile cancer peaks in the sixth decade of life even though it may occur in younger

\footnotetext{
* Correspondence: ayuncasselliii@gmail.com

'Department of Urology and Andrology, Hopital General de Grand Yoff, Dakar, Senegal

2Department of Surgery, Liberia College of Physicians and Surgeons, University of Liberia, Monrovia, Liberia
}

patients. In middle- and low-income countries where circumcision is not routinely practiced, the rate of penile cancer could be ten times higher [4]. Conversely, in Israel where circumcision is performed exclusively for all men at birth; the incidence rate is as low as 0.1 to $0.3 / 100,000$ men $[2,4]$.

The vast majority of patients in Europe and the United States will present with localized disease. This is unlikely in developing nations due to the poor knowledge of the disease, poor access to health care and low socioeconomic status. Most men with cancer in Sub-Saharan Africa (SSA) tend to present with locally advanced to advanced disease portending a dismal prognosis [5]. Penile cancer may result in distressing outcome when diagnosed lately with a five-year survival rate of $50 \%$. When pelvic lymph nodes are involved, the 5-year survival rate may be as low as $0 \%[6]$.

This review has outlined the epidemiology and management of penile cancer in Sub-Saharan African with major highlights of the current standard of care 
considering the European Association of Urologists (EAU) Guideline, European Society for Medical Oncology (ESMO) and National Comprehensive Cancer Network (NCCN) Guideline on Penile Cancer.

\section{Methodology}

The literature review was conducted from 1992 to 2019 using the various search engines and academic databases (PubMed, Google Scholar, African Journal Online and Google. Both English and French Literature search were done using the medical search heading (MEsH) and key words appended "Penile Cancer" or "Cancer Du Penis" with the following indexes: Guidelines, Sub-Saharan Africa, Liberia, Senegal, Ghana, Togo, Nigeria, Benin, Kenya, Zambia, Uganda, Zimbabwe, Tanzania. More than 200 results were found using the search terms. Only 27 articles were selected for the review based on their content either on current management of penile cancer or original article of penile cancer on the SubSaharan or Black African Population.

A total of ten publications of penile cancer with black African subjects were reviewed for demographics, study period, mean age, age range, occupation, comorbidities, risk factors, clinical presentation, histology, staging, management, complications and follow-up (Table 1, 2 and 3). The Tumor-Nodal-Metastasis (TNM) Staging or Jackson Staging of Penile Cancer was documented from various African studies as shown in (Table 2). Relevant data was extrapolated from the text of these publications with both quantitative and qualitative analysis conducted. The synthesized evidence was highlighted in the main text of the results and discussion sessions. The European Association of Urologists (EAU), European Society for Medical Oncology (ESMO) and National Comprehensive Cancer Network (NCCN) Guideline on Penile Cancer were considered for the discussion of penile cancer.

\section{Results}

A total 10 publications [7-16] comprising of 432 black patients with penile cancer were reviewed over a period of 1970 to 2016. A pool analysis of the mean age of men with penile cancer was 52.8 years with a range of 20 years to 83 years. Most of the men in the review were petty farmers, rural inhabitants, low socioeconomic status or unemployed. Data from Guinea, Kenya, Senegal and Tanzania reported uncircumcision and late circumcision as common risk factors $[8,9,11,15]$. Other significant risk factors in the studies were phimosis [7, 15], smoking [7, 15], poor hygiene [16] and repeated history of sexually transmitted diseases [15]. An analysis of six studies among black African with penile cancer showed the rate of concomitant Human Immunodeficiency Virus (HIV) at 20.2\% (Table 1). About eight publications from the Sub-Saharan region did not test for or report the Human Papilloma Virus (HPV) amongst men with penile cancer. However retrospective study from Tanzania of 236 patients with penile cancer reported an

Table 1 Demographics, study period, age parameters, occupation and co-morbididty

\begin{tabular}{|c|c|c|c|c|c|c|}
\hline$\overline{\text { Study }}$ & $\begin{array}{l}\text { Study } \\
\text { Period }\end{array}$ & $\begin{array}{l}\text { Number of } \\
\text { Patients }\end{array}$ & $\begin{array}{l}\text { Mean Age } \\
\text { (years) }\end{array}$ & $\begin{array}{l}\text { Age Range } \\
\text { (years) }\end{array}$ & Occupation & Co-morbidities \\
\hline Ngendaho et al. Rwanda [7] & $2015-2016$ & 30 & $60 \mathrm{yrs}$ & 33 yrs -83 yrs & Petty farmers: $86.7 \%$ & $\begin{array}{l}\text { HIV Infection: } 20 \% \\
\text { HPV: Not tested }\end{array}$ \\
\hline Diallo et al. Guinea [8] & 1996-2013 & 06 & 51 yrs & 32 yrs-80 yrs & N/A & $\begin{array}{l}\text { HIV infection: } 16.7 \% \\
\text { HPV: Not tested }\end{array}$ \\
\hline Magoha et al. Kenya [9] & 1970-1999 & 55 & $47.9 \mathrm{yrs}$ & 20 yrs -80 yrs & $\mathrm{N} / \mathrm{A}$ & $\begin{array}{l}\text { HIV infection: not } \\
\text { tested } \\
\text { HPV: Not tested }\end{array}$ \\
\hline $\begin{array}{l}\text { Wentzel et al. South Africa (Blacks) } \\
{[10]}\end{array}$ & $2000-2008$ & 65 & 50.9 yrs & $37 y r-69 y r s$ & $N / A$ & $\begin{array}{l}\text { HIV Infection: } 56.2 \% \\
\text { HPV: } 41.5 \%\end{array}$ \\
\hline Gueye et al. Senegal [11] & 10 years & 11 & $55 \mathrm{yrs}$ & 40 yrs -75 yrs & $\mathrm{N} / \mathrm{A}$ & $\begin{array}{l}\text { HIV: } 9.1 \% \\
\text { HPV: Not tested }\end{array}$ \\
\hline Ajekigbe et al. Nigeria [12] & 1990-2009 & 07 & $52.2 \mathrm{yrs}$ & 42 yrs-79 yrs & $\mathrm{N} / \mathrm{A}$ & $\begin{array}{l}\text { HIV infection: not } \\
\text { tested } \\
\text { HPV: Not tested }\end{array}$ \\
\hline Sow et al. Cameroon [13] & 1994-2005 & 08 & N/A & 43 yrs-75 yrs & Rural inhabitants: 100\% & $\begin{array}{l}\text { HIV infection: } 12.5 \% \\
\text { HPV: Not tested }\end{array}$ \\
\hline Abdulkadir et al. Nigeria [14] & $1998-2015$ & 06 & 59.7 yrs & 50 yrs -75 yrs & & \\
\hline Chalya et al. Tanzania [15] & 2004-2013 & 236 & $47 \mathrm{yrs}$ & 21 yrs-78 yrs & Unemployed & $\begin{array}{l}\text { HIV infection: } 6.7 \% \\
\text { HPV: } 5.1 \%\end{array}$ \\
\hline Sow et al. Senegal [16] & $2000-2011$ & 08 & $51.5 \mathrm{yrs}$ & 27 yrs-77 yrs & $\begin{array}{l}\text { Low socioeconomic } \\
\text { status }\end{array}$ & \\
\hline
\end{tabular}


Table 2 Risk factors, clinical presentation, histology and staging

\begin{tabular}{|c|c|c|c|c|c|c|}
\hline Study & Risk Factors & Clinical Presentation & Histology & Stage (TMN/Jackson) & $\begin{array}{l}\text { ILN status + } \\
\text { Metastasis }\end{array}$ & Grade + Metastasis \\
\hline $\begin{array}{l}\text { Ngendaho et al. } \\
\text { [7] }\end{array}$ & $\begin{array}{l}\text { Phimosis: } 50 \% \text { Poor } \\
\text { Hygiene: } 80 \% \\
\text { Smoking: } 56.7 \% \\
\text { Lichen Sclerosis: } 13.3 \%\end{array}$ & $\begin{array}{l}\text { Subpreputial symptoms: } \\
63.3 \% \\
\text { Penile Ulceration:26.7\% } \\
\text { Meatal lesion: } 10 \%\end{array}$ & $\begin{array}{l}\text { SCC: } \\
100 \%\end{array}$ & $\begin{array}{l}\text { T1:3.3\% } \\
\text { T2: 36.7\%T3: } \\
\text { 56.7\%T4:3.3\% }\end{array}$ & $\begin{array}{l}\text { N0:43.3\% } \\
\text { N1:20\% } \\
\text { N2:23.3\% } \\
\text { N3:13.3\% } \\
\text { M1: } 16.7 \%\end{array}$ & $\begin{array}{l}\text { G1:43.3\% G2: 50\% G3: } \\
6.7 \%\end{array}$ \\
\hline Diallo et al. [8] & Late Circumcision: $66.7 \%$ & $\begin{array}{l}\text { Fungating } \\
\text { Ulcerated }\end{array}$ & $\begin{array}{l}\text { SCC: } \\
100 \%\end{array}$ & $\begin{array}{l}\text { T1:16.7 } \\
\text { T2:33.3\% } \\
\text { T3:50\% }\end{array}$ & $\begin{array}{l}\mathrm{N} 2: 66.7 \% \\
\mathrm{M} 1: 16.7 \%\end{array}$ & $\begin{array}{l}\text { G1:33.3\% } \\
\text { G2:16.7\% } \\
\text { G3:50\% }\end{array}$ \\
\hline $\begin{array}{l}\text { Magoha et al. } \\
{[9]}\end{array}$ & $\begin{array}{l}\text { Uncircumcision: } 72.7 \% \\
\text { Late Circmcision: } 21.8 \%\end{array}$ & N/A & $\begin{array}{l}\text { SCC: } \\
100 \%\end{array}$ & $\begin{array}{l}\text { Stage 1: } 18.2 \% \\
\text { Stage 2: } 12.7 \% \\
\text { Stage 3: } 50.9 \% \\
\text { Stage 4: } 18.2 \%\end{array}$ & $\mathrm{~N} / \mathrm{A}$ & N/A \\
\hline $\begin{array}{l}\text { Wentzel et al. } \\
{[10]}\end{array}$ & N/A & N/A & $\begin{array}{l}\text { SCC: } 80 \% \\
\text { VC: } \\
15.4 \%\end{array}$ & $\mathrm{~N} / \mathrm{A}$ & $\mathrm{N} / \mathrm{A}$ & $\mathrm{N} / \mathrm{A}$ \\
\hline Gueye et al. [11] & $\begin{array}{l}\text { Uncircumcision: } 18.2 \% \\
\text { Late Circmcision: } 27.3 \% \\
\text { Phimosis: } 18.2 \%\end{array}$ & N/A & $\begin{array}{l}\text { SCC: } \\
90.9 \%\end{array}$ & $\begin{array}{l}\text { Stage 1: } 36.4 \% \\
\text { Stage 2: } 45.5 \% \\
\text { Stage 3: } 18.2 \%\end{array}$ & $\begin{array}{l}\text { N: } 27.3 \% \\
\text { M1: } 0 \%\end{array}$ & N/A \\
\hline $\begin{array}{l}\text { Ajekigbe et al. } \\
{[12]}\end{array}$ & N/A & $\begin{array}{l}\text { Ulcerated } \\
\text { Warty }\end{array}$ & $\begin{array}{l}\text { SCC: } \\
100 \%\end{array}$ & $\mathrm{~N} / \mathrm{A}$ & $\mathrm{N} / \mathrm{A}$ & N/A \\
\hline Sow et al. [13] & $\begin{array}{l}\text { Childhood circumcision: } \\
100 \%\end{array}$ & $\begin{array}{l}\text { Ulceration } \\
\text { Fungating } \\
\text { Fungating + Ulcerated }\end{array}$ & $\begin{array}{l}\text { SCC: } \\
87.5 \% \\
\text { NHL: } \\
12.5 \%\end{array}$ & Stage $3 \& 4: 100 \%$ & N2\&N3: 100\% & N/A \\
\hline $\begin{array}{l}\text { Abdulkadir et al. } \\
{[14]}\end{array}$ & N/A & N/A & $\begin{array}{l}\text { SCC: } \\
100 \%\end{array}$ & $\mathrm{~N} / \mathrm{A}$ & $\mathrm{N} / \mathrm{A}$ & N/A \\
\hline Chayla et al. [15] & $\begin{array}{l}\text { Uncircumcision: } 89.8 \% \\
\text { Smoking: } 77.1 \% \\
\text { Phimosis: } 62.3 \% \\
\text { Repeated STDs: } 22.9 \%\end{array}$ & & $\begin{array}{l}\text { SCC: } \\
99.2 \%\end{array}$ & $\begin{array}{l}\text { Stage 1: } 10.2 \% \\
\text { Stage 2: } 11.2 \% \\
\text { Stage 3: } 55.9 \% \\
\text { Stage 4: } 12.7 \%\end{array}$ & $\begin{array}{l}\text { N: } 65.3 \% \\
\text { M: } 4.2 \%\end{array}$ & \\
\hline Sow et al. [16] & Poor hygiene & Fungating + Ulcerated & $\begin{array}{l}\text { SCC: } \\
100 \%\end{array}$ & $\begin{array}{l}\text { T1: } 12.5 \% \\
\text { T2: } 50 \% \\
\text { T3: } 37.5 \% \\
\text { T4: } 00 \%\end{array}$ & $\begin{array}{l}\text { N0: } 62.5 \% \\
\text { N1: } 00 \% \\
\text { N2: } 12.5 \% \\
\text { N3: } 37.5 \% \\
\text { M1: } 00 \%\end{array}$ & $\begin{array}{l}\text { G1: } 25 \% \\
\text { G2: } 62.5 \% \\
\text { G3: } 12.5 \%\end{array}$ \\
\hline
\end{tabular}

G Grade, M Metastasis, N Node, NHL Non-Hodgkin Lymphoma, N/A Not Available, SCC Squamous Cell Carcinoma, $T$ Tumor

associated HPV infection rate of 5.1\%. Wentzel et al. from South Africa reviewing 65 African men with penile cancer showed a concomitant HPV infection rate of $4.5 \%$. Most of these Sub-Saharan studies reported ulcerated, fungating, or both as the commonest presentation of men with penile cancer Fig. 1 (a-b). Squamous cell carcinoma was the predominant histological feature of men with penile cancer in the Sub-Saharan region at rate of $95.8 \%$. Both the Tumor-Nodal-Metastasis (TNM) Staging and Jackson Staging of Penile Cancer were used (Table 2). Moreover, most men with penile cancer from the review presented predominantly with locally advanced to advanced disease. A pool analysis of 8 studies from the review showed the glans alone was commonly affected at $43.1 \%$, glans + Penile Shaft $(42.0 \%)$, Penile Shaft alone (26.8\%), and Prepuce (15.1\%). Reports from Rwanda, Guinea, Cameroon and Senegal revealed that partial penectomy, total penectomy + inguinal lymph node dissection, emasculation were all management options without reporting chemotherapy or radiotherapy (Table 3). However, findings from Kenya and Tanzania reported the use of adjuvant radiation therapy, adjuvant chemotherapy or adjuvant chemoradiation for men with penile cancer. An average of $43.7 \%$ of men with penile cancer from Guinea and Senegal declined penectomy. Surgical site infection, scrotal edema, lymphocele, skin necrosis, meatal stenosis, deep vein thrombosis, chronic pain were complications mentioned. Most of these men were lost to follow after a year.

\section{Etiology and risk factors}

The Human Papilloma virus (HPV) have been identified as etiological agents associated with penile cancer. HPV Isotypes 16 and 18 have been proven to induce carcinogenesis for penile cancer. Studies from Thailand, Denmark, and Spain showed an HPV prevalence ranging from 55 to $65 \%$ [4]. Another review of 31 publication involving 1466 patients with penile cancer revealed an 
Table 3 Management, Complication and Follow-up

\begin{tabular}{|c|c|c|c|c|c|}
\hline Study & Locality of lesion & Surgery & $\begin{array}{l}\text { Chemo/ } \\
\text { Radiotherapy }\end{array}$ & Complication & Follow-up \\
\hline $\begin{array}{l}\text { Ngendaho } \\
\text { et al. [7] }\end{array}$ & Glans: $46.7 \%$ & $\begin{array}{l}\text { Partial Penectomy: } \\
\text { 80\% } \\
\text { Total Penectomy: } \\
\text { 13.3\% } \\
\text { Penectomy + ILND: } \\
33.3 \%\end{array}$ & $\mathrm{~N} / \mathrm{A}$ & $\begin{array}{l}\text { SSI:10\%; Lymphocele:10\%, Skin necrosis, } \\
\text { Death, Meatal stenosis }\end{array}$ & $\begin{array}{l}0 \% \text { recurrence at } 6 \\
\text { months }\end{array}$ \\
\hline Diallo et al. [8] & $\begin{array}{l}\text { Glans: } 33.3 \% \\
\text { Glans + Penile } \\
\text { Shaft: } 66.7 \%\end{array}$ & $\begin{array}{l}\text { PP: } 16.7 \% \\
\text { TP + ILND: } 16.7 \% \\
\text { Emasculation:16.7\% } \\
\text { Decline Treatment: } \\
33.3 \%\end{array}$ & N/A & N/A & $\begin{array}{l}50 \% \text { Loss to follow-up } \\
1 \text {-year mortality } 33.3 \%\end{array}$ \\
\hline $\begin{array}{l}\text { Magoha et al. } \\
{[9]}\end{array}$ & $\begin{array}{l}\text { Glans: } 43.6 \% \\
\text { Glans + Penile } \\
\text { Shaft: } 21.8 \% \\
\text { Prepuce: } 12.7 \%\end{array}$ & $\begin{array}{l}\text { Circumcision: } 3.6 \% \\
\text { Local Excision + } \\
\text { Rad: } 7.2 \% \\
\text { PP + Rad: } 20.1 \% \\
\text { PP + Chemo: } 5.5 \% \\
\text { PP + Chemo + rad: } \\
\text { 10.9\% } \\
\text { TP + Rad: } 14.5 \%\end{array}$ & $\begin{array}{l}\text { Rad alone: } \\
9.1 \% \\
\text { Chemo + Rad: } \\
10.9 \%\end{array}$ & $\mathrm{~N} / \mathrm{A}$ & N/A \\
\hline $\begin{array}{l}\text { Gueye et al. } \\
{[11]}\end{array}$ & $\begin{array}{l}\text { Glans: } 36.4 \% \\
\text { Glans + Shaft: } \\
45.5 \%\end{array}$ & $\begin{array}{l}\text { Partial Penectomy: } \\
\text { 18.2\% } \\
\text { Total Penectomy: } \\
\text { 9.1\% } \\
\text { Decline Treatment: } \\
\text { 72.7\% }\end{array}$ & N/A & N/A & $100 \%$ Loss to Follow-up \\
\hline $\begin{array}{l}\text { Ajekigbe et al } \\
{[12]}\end{array}$ & Penile Shaft: $42.9 \%$ & N/A & N/A & N/A & N/A \\
\hline Sow et al. [13] & $\begin{array}{l}\text { Glans: } 62.5 \% \% \\
\text { Shaft: } 12.5 \% \\
\text { Prepuce: } 25 \%\end{array}$ & $\begin{array}{l}\text { TP: } 37.5 \% \\
\text { Emasculation + } \\
\text { ILND: } 12.5 \%\end{array}$ & $\mathrm{~N} / \mathrm{A}$ & N/A & Loss to follow-up: 50\% \\
\hline $\begin{array}{l}\text { Abdulkadir } \\
\text { et al. [14] }\end{array}$ & $\begin{array}{l}\text { Glans: } 50 \% \\
\text { Glans + Prepuce: } \\
33.3 \% \\
\text { Shaft: } 16.7 \%\end{array}$ & & & & \\
\hline $\begin{array}{l}\text { Chayla et al. } \\
{[15]}\end{array}$ & $\begin{array}{l}\text { Glans: } 60.1 \% \\
\text { Glans + Shaft: } \\
13.6 \% \\
\text { Prepuce: } 7.6 \%\end{array}$ & $\begin{array}{l}\text { Partial penectomy: } \\
63.1 \% \\
\text { Total Penectomy: } \\
10.8 \% \\
\text { ILND: 16.8\% } \\
\text { Penile sparing: } \\
9.3 \%\end{array}$ & $\begin{array}{l}\text { Chemo: } 5.9 \% \\
\text { Rad: } 5.1 \%\end{array}$ & $\begin{array}{l}\text { SSI: } 44.8 \% ; \\
\text { DVT: } 15.5 \% \\
\text { Chronic Pain: } 13.8 \% \\
\text { Scrotal edema: } 10.3 \%\end{array}$ & $\begin{array}{l}76.1 \% \text { loss to follow-up } \\
\text { at } 5 \text { years } \\
\text { Mortality: } 10 \% \\
\text { Recurrence: } 5.3 \%\end{array}$ \\
\hline Sow et al. [16] & $\begin{array}{l}\text { Glans: } 12.5 \% \\
\text { Glans + Shaft: } \\
62.5 \% \\
\text { Shaft: } 25 \%\end{array}$ & $\begin{array}{l}\text { Partial Penectomy: } \\
62.5 \% \\
\text { TP + ILND: } 12.5 \% \\
\text { Decline Treatment: } \\
25 \%\end{array}$ & & & $\begin{array}{l}25 \% \text { loss to follow-up } \\
\text { Recurrence: } 12.5 \% \\
\text { Death: } 12.5 \%\end{array}$ \\
\hline
\end{tabular}

DVT: Chemo: Chemotherapy; Deep Venous Thrombosis, ILND: Inguinal Lymph Node Dissection; N/A: Not Available; PP: Partial Penectomy; Rad: Radiotherapy; SSI: Surgical Site Infection; TP: Total Penectomy

overall prevalence of HPV at $46.9 \%$ with dominant subtypes HPV 16 (60.2\%) and HPV 18 (13.4\%) [17]. Patients with Human Immunodeficient Virus (HIV) have an 8fold increase risk of HPV infection [6] thus stipulating an essential correlation between HIV and penile cancer. Study by Wentzel et al. evaluating black South African male with penile cancer found that patients with HIV infection were more likely to develop HPV associated penile cancer at a younger age [10].
The association between the lack of circumcision and penile cancer have been well established from several studies. A meta-analysis of 7 case control studies showed a strong protective effect of childhood circumcision against invasive penile cancer ( $\mathrm{OR}=0.33$; $95 \%$ CI 0.13 0.83 ) [18]. However, this protective effective of early circumcision was eliminated when boys with no history of phimosis were analyzed. Phimosis is a strong risk factor for invasive penile cancer with the accumulation of 

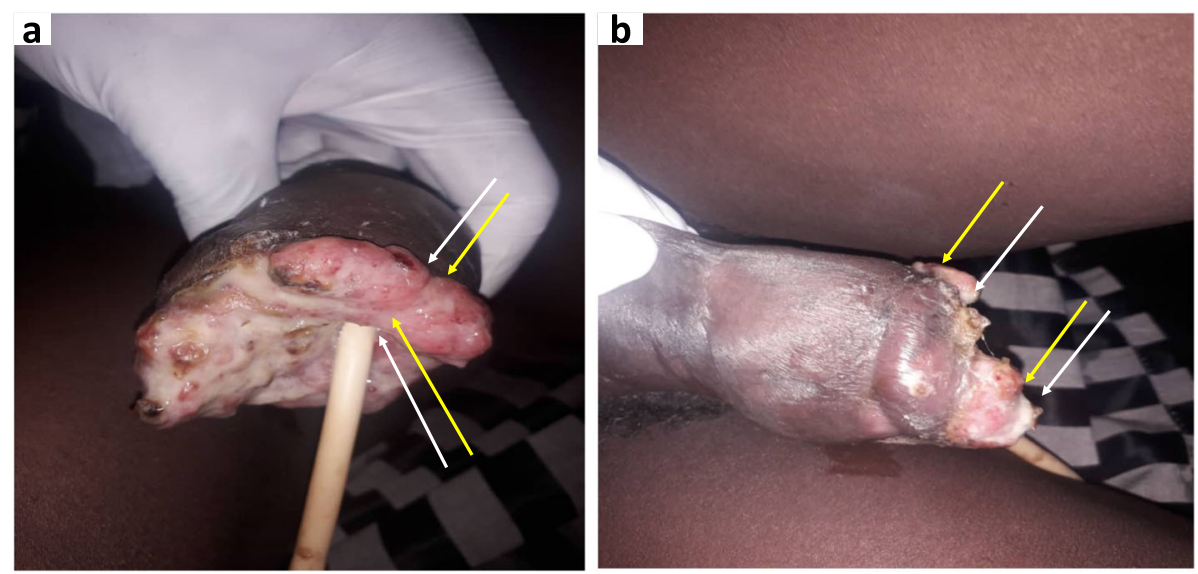

Fig. 1 a-b Shows an advanced ulcerated and fungated penile mass that has eroded the glans, the corpora bodies and urethra

smegma causing repeated chronic inflammation and subsequent carcinogenesis [18]. It can be deduced that circumcision thus eliminates the risk of phimosis that could cause penile cancer. Chronic cigarette smoking, lichen sclerosis (balanitis xerotica obliterans), low socioeconomic status and education have been found as risk factors $[2,19]$.

The lack of circumcision as a risk in SSA remains heterogenous. Some African nations $[8,11]$ practice childhood circumcision as a routine ritual thus eliminating an important risk of penile cancer while others like Kenya [9] and Tanzania [15] have high rates of uncircumcised males. Despite the variation in these settings, low socioeconomic status, education and poor hygiene remain a unique challenge amongst most regions in Africa. Results from a study in Uganda showed that there was a higher rate of HPV infection from swabs of uncircumcised adult males compared to swabs taken after a year of circumcision (28\% versus $18 \%$ ) [4]. This data revealed that circumcision may have a protective effect against HPV infection which could portend a lower risk of penile cancer. Even with the close association of HPV infection and penile cancer, most men with penile cancer in SSA were not tested considering results from the review.

\section{Clinical presentation}

Penile cancer may present as visible lesion along the glans, prepuce or the penile shaft. It may be associated with pain, discharge, bleeding or malodorous based on the stage of the disease. The disease presentation can be described as nodular, ulcerative or fungating [6]. In some cases, penile cancer can be concealed by phimosis. In advanced cases of penile cancer, constitutional symptoms (fatigue, weight loss) and palpable inguinal lymph nodes could be present [6]. Most men with penile disease in SSA present with advanced stages of penile cancer either due to lack of knowledge, socioeconomic status or fear of the treatment options. Therefore, common clinical presentation reported from Rwanda [7], Guinea [8], Nigeria [12], Cameroon [13], and Senegal [16] included penile ulceration, fungating mass or ulcero-fungating mass Fig. 1 (a-b). These clinical descriptions denote a late presentation of the disease.

\section{Pathology}

Squamous cell carcinoma (SCC) is the predominant histological type in $90 \%$ of penile cancer. SCC of the penis can be further categorized as basaloid, verrucous and papillary types $[2,19]$. Less common histological variants include adenocarcinoma, melanoma and sarcoma. The growth pattern could be superficial spreading, nodular, vertical growth or verrucous growth [1]. Race and geographical variations did not affect much the histological type of penile cancer as this review displayed SCC the commonest among SSA males with an average of $95.8 \%$.

\section{Diagnosis and staging}

The diagnosis of penile cancer is confirmed by biopsy. Pathological report is essential to drive treatment plan and lymph node management. Excisional biopsy is ideal to assess the degree of invasion and stage of the disease. Intraoperative fresh frozen section can depict negative surgical margin; $5 \mathrm{~mm}$ of tumor free margin is considered oncologically adequate [2]. Perform physical exam and document the number of nodes, morphology and laterality. If inguinal lymph nodes are not palpable, offer invasive lymph node staging for only high-risk patients. Otherwise, imaging (Ultrasound, Magnetic Resonance Imaging (MRI) Computed Tomography (CT) scan) may not be helpful to detect micro metastasis. Patient with palpable inguinal lymph node may require pelvic, abdominal and thoracic CT-scan to assess pelvic lymph nodes and distant metastasis $[1,2]$. 
The American Joint Committee on Cancer (AJCC) tumor, nodes and metastases (TNM) classification has staged penile cancer for prognostic purposes. Stage 0 (Tis, Ta, N0, M0: non-invasive verrucous carcinoma or carcinoma in situ) has a $90-100 \%$ five-year survival rate [19]. Similarly, Stage 1 (T1a, N0, M0: with no evidence of lympho-vascular invasion LVI) has a 5-year overall survival of between 90 and $100 \%$. Stage 2 (T1b/T2/T3, N0, M0: LVI/ undifferentiated/poorly differentiated/ tumor invades corpus cavernosa/ corpora spongiosum or urethra) also has a good prognosis after treatment [19]. Stage 3A (T1-3, N1, M0) single, unilateral lymph node has an overall 5 -year survival (OS) rate at $80 \%$. Contrarily, Stage 3B (T1-3, N2, M0) multiple unilateral or bilateral inguinal lymph nodes has a 5-year OS of 40\%. More advanced Stage 4 (any T4, any N3, any M1) T4 - invades contiguous structures, N3 - fixed inguinal or pelvic lymph nodes, or metastatic disease has a dismal 5 -year OS at 11\% [19]. According to the AJCC, SCC of the penis is graded based on the degree of cell anaplasia [20]. Grade- 1 is considered well differentiated, grade- 2 is moderately differentiated, grade- 3 is poorly differentiated while grade- 4 is undifferentiated [20].

Like most other late cancer presentation in SSA [5], most patient in the review presented with locally advanced to advanced penile cancer. In the absence of relevant education, men in SSA see it as a taboo to communicate about genital problems. There is also a misconception that every penile lesion may lead to total penectomy or emasculation if reported to a health facility. The unfortunate paradox is that this fear and misconception leads to very late presentation amongst SSA men with penile cancer actually necessitating these mutilating procedures.

\section{Recommended management guideline $\mathrm{Tis} / \mathrm{Ta}$}

Patients with non-invasive verrucous carcinoma or penile carcinoma in situ can benefit from penile preserving modalities including topical 5-fluorouracil or 5\% topical imiquimod [1, 2, 6]. Circumcision, wide local excision (Mohs procedure), partial/complete glansectomy as well as laser therapy (carbon dioxide or neodynium:yttrium-aluminum-garnet) have shown good results $[1,2,6]$.

\section{T1/G1-2}

Penile preserving procedures should be carefully selected in patients regarding the ability for follow-up. Studies have shown that the 2-year recurrence rate may approach 50\% [11]. Circumcision, wide local excision (Mohs procedure), partial/complete glansectomy, laser therapy or radiotherapy (external beam or brachytherapy) have been indicated as treatment options. Current evidence has shown that a surgical margin of $5 \mathrm{~mm}$ possesses similar oncological safety as 2-cm margin [6].

\section{$T 1 / G 3-4, T \geq 2$}

Partial or total penectomy will be require for these lesions considering the characteristics of the tumor and depth of invasion. Intraoperative fresh frozen section should be used to attain negative surgical margin. For select patients with tumor occupying less than half of the glans, wide local excision or glansectomy are options if the patients can adhere to strict follow-up plans [6]. The possibility of repeat wide local excision for local recurrence without cavernosa invasion or partial/total penectomy for a more invasive disease should be discussed with the patient. For lesion less than $4 \mathrm{~cm}$, radiotherapy by external beam or as brachytherapy are treatment option $[2,6]$.

The management of invasive disease confined to the corpus spongiosum or glans (T2) include total glansectomy with reconstruction of the corporal head. The treatment of disease involving the corpora cavernosa and/or urethra (T2/T3) include partial penectomy with reconstruction [2, 21]. Radiotherapy should be considered as an alternative but will require circumcision first. Patient with locally advanced (T3) penile cancer should be treated with total penectomy with a perineal urethrostomy. More advanced (T4) disease should require neoadjuvant chemotherapy followed by surgery when response is observed [2, 21]. However, adjuvant chemotherapy or palliative radiation are alternatives.

\section{Management of Lymph Nodes \\ Nonpalpable lymph nodes}

Clinically negative node patients with low risk (Tis, Ta, T1G1) and intermediate risk (T1G2) can undergo surveillance. However, patients with nonpalpable inguinal lymph node with intermediate risk and high-risk penile cancer dynamic sentinel node biopsy (DSNB) is recommended $[1,2,6]$. Inguinal lymph node dissection is recommended if a positive node is identified.

\section{Unilateral or bilateral palpable inguinal nodes [1, 2, 6]}

For patients with palpable lymph node, a Fine needle aspiration is recommended. If results are equivocal, an excisional biopsy is indicated to confirm. In the presence of a positive lymph node, an immediate inguinal lymph node dissection should be performed. When greater than two nodes are positive or extranodal disease, a pelvic lymph node dissection is recommended. Adjuvant chemotherapy should also be considered.

\section{Fixed or ulcerated inguinal lymph node [1, 2, 6]}

The risk of metastasis is very high in these patients therefore, pelvic, abdominal CT-scan is indicated. 
Multimodal treatment with neoadjuvant chemotherapy with subsequent radical lymph node dissection in those with clinical nodal response.

\section{Recurrent regional lymph node $[1,2,6]$}

There is no level evidence for the ideal management of recurrent nodal disease. However, multimodal treatment including radical lymph node dissection, chemotherapy or radiotherapy are options.

\section{Metastatic penile cancer}

Systemic chemotherapy, radiotherapy or chemoradiation should be considered for patients with metastatic disease. The first line systemic chemotherapy regimen is cisplatin based (paclitaxel, ifosfomide + cisplatin or 5 Fluorouracil + cisplatin) $[2,6]$. Radiotherapy may be used for palliation. Immunotherapy like pembrolizumab can be used as a second line. Advanced case of penile cancer refractory to systemic therapy tend to rely on supportive care. The mean 5-year overall survival for metastatic penile cancer is about $10 \%[6,22]$.

Considering the late presentation of penile cancer from this review, more mutilating procedures were required compare to penile preserving surgeries. Data from Guinea and Senegal showed a high rate of decline from surgeries after surgeons suggested penectomy as a treatment plan. The use of chemotherapy or radiotherapy was barely reported except for data from Kenya and Tanzania that used adjuvant chemotherapy or radiotherapy in few patients $[9,15]$. Most of the region lack cancer treatment centers as well urologist, oncologist or radiation oncologist. Radiotherapy is sparsely distributed on the African Continent with South Africa and Egypt have the most centers [23]. The World Health Organization (WHO) declared that there are only 22 chemotherapeutic agents available to Africa at varying time, but these drugs are rather too expensive for an average person from SSA [23]. This mishap is worsened by the population at risk for penile cancer; those of low socioeconomic status that cannot afford treatment.

\section{Follow-up}

The goal of follow-up is to detect early recurrences that could be curable and the management of treatment related complication. A more intense follow-up regimen is recommended during the first 2 years where recurrence is expected to be high. A less rigid follow-up plan can continue up to 5 years; thereafter which patient can carry out self-examination at home $[1,2,6]$.

The follow-up in the review was dismal amongst men managed for penile cancer in SSA ranging from $25 \%$ to 100 loss to follow-up. Most patients are psychologically and emotionally challenged after penile procedures and may not return to the health institution knowing that their penile length will not be restored. The cost of treatment, distance from major cancer center and unreported death at home may be contributing factors.

\section{Quality of life after penile procedures}

Evidence has shown that there is acceptable sexual activity and quality of life after penile sparing procedures like laser surgery or wide local excision. However, some decline in sexual activities have been observed after glansectomy and more after partial penectomy [2, 24]. The challenge has been the length of the penile stump may not be suitable for satisfactory sexual intercourse [2, 24]. Some patients have reported to loss self-esteem as well as sexual pleasure. A strong family support system should be established before proceeding to penile procedures. The psychological well-being of the patients as well as the partners have a crucial role to play in the follow-up process.

\section{Prevention strategies and recommendation}

Neonatal circumcision as practiced by the Jews has seem to mitigate the risk of phimosis thus reducing the incidence of penile in this population $[2,6,15]$. Some regions are now suggesting routine neonatal circumcision as means to reduce the risk of penile cancer. Increasing daily hygiene and preventing sexually transmitted infection could be helpful in alleviating the risk of penile cancer [25]. The HPV vaccine has been shown to the reduce the transmission of HPV infection thus reducing the risk of cervical cancer in female and precancerous anal lesions in men [26]. It is postulated that the HPV vaccine could provide some protection against penile cancer in men by preventing the transmission of HPV infection. There is still some skepticism about the cost effectiveness of HPV vaccination while others are concerned that it may increase male promiscuity. However, in the context of SSA, neonatal circumcision seems the most cost-effective option.

\section{Conclusion}

Penile cancer is rare with SCC being the commonest histological type. HPV, lack of circumcision, phimosis, poor hygiene and low socioeconomic status are established risk factors. Most men with penile cancer in SSA present with locally advanced to advanced disease with devastating consequences. The option of penile sparing procedure is reduced with most resulting to mutilating surgeries. The lack of appropriate chemotherapy and radiotherapy worsens the prognosis in the region. HPV vaccination may not be cost-effective for most regions in SSA therefore, neonatal circumcision might be the best advocated alternative for prevention. 


\section{Abbreviations}

HIV: Human Immunodeficient Virus; HPV: Human Papilloma Virus; SSA: SubSaharan Africa; TNM: Tumor-Nodal-Metastasis; WHO: World Health Organization

\section{Acknowledgements}

Special thanks to the Department of Surgery of the John F. Kennedy Medical Center, Monrovia Liberia.

\section{Authors' contributions}

All Authors have read and approved this manuscript for publication- Conceptual design: AC, BY, BM, DW. Analysis, drafting and critical revision of the article: AC, BY, BM, DW. Final approval of the article: All authors have read and approved this manuscript for publication

\section{Funding}

No external funding available to disclose.

\section{Availability of data and materials}

Not applicable.

\section{Ethics approval and consent to participate}

The manuscript has been drafted in accordance with the Declaration of Helsinki and has met ethical approval granted by the Department of Surgery, Liberian College of Physician and Surgeons.

\section{Consent for publication}

Not applicable.

\section{Competing interests}

The authors declare no conflict of interest regarding this article.

Received: 12 March 2020 Accepted: 22 April 2020

Published online: 01 May 2020

\section{References}

1. Van Poppel H, Watkin NA, Osanto S, Moonen L, Horwich A, Kataja V, ESMO Guidelines Working Group. Penile cancer: ESMO Clinical Practice Guidelines for diagnosis, treatment and follow-up. Ann Oncol. 2013;24(suppl_6):vi115-24.

2. Hakenberg OW, Compérat E, Minhas S, Necchi A, Protzel C, Watkin N. EAU guidelines on penile cancer. Eur Assoc Urol. 2014. p. 13-7. Available from: http://uroweb.org/guideline/penile-cancer/.

3. Wabinga HR, Parkin DM, Wabwire-Mangen F, Nambooze S. Trends in cancer incidence in Kyadondo County, Uganda, 1960-1997. Br J Cancer. 2000;82(9): 1585.

4. Morris BJ, Gray RH, Castellsague X, Bosch FX, Halperin DT, Waskett JH, Hankins CA. The strong protective effect of circumcision against cancer of the penis. Advances Urol. 2011:2011:1-21.

5. Cassell A, Yunusa B, Jalloh M, Ndoye M, Mbodji MM, Diallo A, Kouka SC, Labou I, Niang L, Gueye SM. Management of Advanced and Metastatic Prostate Cancer: a need for a sub-Saharan guideline. J Oncol. 2019;2019:1-9. https://doi.org/10.1155/2019/1785428.

6. Clark PE, Spiess PE, Agarwal N, et al. Penile cancer: clinical practice guidelines in oncology. J Natl Compr Cancer Netw. 2013;11(5):594-615. https://doi.org/10.6004/jnccn.2013.0075.

7. Ngendahayo E, Nzayirambaho M, Bonane A, Gasana GA, Ssebuufu R, Umurangwa F, Muhawenimana E, Nyirimodoka A, Nzeyimana I, Rugwizangoga B, Muvunyi TZ. Pattern and clinical management of penile cancer in Rwanda. Afr J Urol. 2018:24(4):274-81.

8. Diallo AB. Le cancer du penis: particularites anatomo-cliniques et difficultes therapeutiques en quinee. Revue Africaine d'Urologie et d'Andrologie. 2017; 23:1 (8):341-8.

9. Magoha GA, Ngumi ZW. Cancer of the penis at Kenyatta National Hospital. East Afr Med J. 2000:77(10):526-30.

10. Wentzel SW, Vermeulen LP, Beukes CA, Thiart J, Joubert G, Goedhals J. Human immunodeficiency virus (HIV) infection in men with penile carcinoma is associated with increased prevalence of human papilloma virus infection and younger age at presentation. S Afr J Surg. 2018;56(3):47-50.

11. Gueye SM, Diagne BA, Ba M, Sylla C, Mensah A. Le cancer de la verge: aspects épidémiologiques et problèmes thérapeutiques au Sénégal. Médecine d'Afrique Noire. 1992;39(8/9).
12. Ajekigbe AT, Anunobi CC, Tijani KH, Banjo AA, Nweke IG. Carcinoma of the penis: experience from the Lagos University teaching hospital Lagos, Nigeria. Nigerian Quarterly J Hospital Med. 2011;21(1):25-8.

13. Sow M, Nkegoum B, Moor VA, Decremoux P, Sastre-Garau X. Les tumeurs malignes du pénis au Cameroun : aspects épidémiologiques, cliniques, anatomopathologiques et thérapeutiques. In Annales de Pathologie 2006 Sep 1 (Vol. 26, No. 4, pp. 299-301). Elsevier Masson.

14. Abdulkadir A, Alhaji SA, Sanusi HM. Pattern of penile cancers in Kano. Niger J Basic Clin Sci. 2017;14:15-7.

15. Chalya PL, Rambau PF, Masalu N, Simbila S. Ten-year surgical experiences with penile cancer at a tertiary care hospital in northwestern Tanzania: a retrospective study of 236 patients. World J Surg Oncol. 2015;13(1):71.

16. Sow Y, Thiam A, Fall B, Coulibali M, Sarr A, Diao B, Fall PA, Ndoye AK, Ba M, Diagne BA. Cancer du pénis au Sénégal: aspects cliniques et thérapeutiques. Basic Clin Androl. 2012:22(2):102.

17. Miralles-Guri C, Bruni L, Cubilla AL, Castellsague X, Bosch FX, De Sanjose S. Human papillomavirus prevalence and type distribution in penile carcinoma. J Clin Pathol. 2009;62(10):870-8.

18. Larke NL, Thomas SL, dos Santos SI, Weiss HA. Male circumcision and penile cancer: a systematic review and meta-analysis. Cancer Causes Control. 2011; 22(8):1097-110.

19. Kane C, Sellers $L$, Miller R. Diagnosis and management of penile cancer. Trends Urol Men's Health. 2016;7(5):17-20.

20. Edge, SB.; Byrd, DR.; Compton, CC., et al., Editors. AJCC Cancer staging manual. 7. New York: Springer; 2010.

21. Ornellas AA et al. Surgical treatment of invasive squamous cell carcinoma of the penis: Brazilian National Cancer Institute long-term experience. J Surg Oncol. 2008:97:487.

22. Lopes A, Bezerra AL, Serrano SV, Hidalgo GS. lliac nodal metastases from carcinoma of the penis treated surgically. BJU Int. 2000;86:690-3.

23. Stefan DC. Cancer care in Africa: an overview of resources. J Global Oncol. 2015;1 (1):30-6.

24. D'Ancona CA, et al. Quality of life after partial penectomy for penile carcinoma. Urology. 1997;50:593.

25. Tang DH, Spiess PE. Should routine neonatal circumcision be a policy to prevent penile cancer? | opinion: no. Int Braz J Urol. 2017;43(1):10-2.

26. Okuku F, Omoding A, Walusansa V, Origa M, Mutungi G, Orem J. Infectionrelated cancers in sub-Saharan Africa: a paradigm for cancer prevention and control. Oncology. 2013;84(2):75-80

\section{Publisher's Note}

Springer Nature remains neutral with regard to jurisdictional claims in published maps and institutional affiliations.

Ready to submit your research? Choose BMC and benefit from:

- fast, convenient online submission

- thorough peer review by experienced researchers in your field

- rapid publication on acceptance

- support for research data, including large and complex data types

- gold Open Access which fosters wider collaboration and increased citations

- maximum visibility for your research: over $100 \mathrm{M}$ website views per year

At BMC, research is always in progress.

Learn more biomedcentral.com/submissions 